\title{
Effect of turmeric and garlic supplementation to fermented Sauropus androgynus-bay leaves containing diet on fat deposition and broiler meat composition
}

\author{
U. Santoso*, Y. Fenita, K. Kususiyah and A. Agustian \\ Animal Husbandry Department, Agriculture Faculty, University of Bengkulu, \\ Jln. W.R. Soepratman, Kota Bengkulu - Indonesia \\ *Corresponding E-mail: santoso@unib.ac.id \\ Received January 29, 2020; Accepted May 14, 2020
}

\begin{abstract}
ABSTRAK
Penelitian ini bertujuan untuk menguji pengaruh suplementasi kunyit dan bawang putih ke dalam pakan yang mengandung daun katuk-salam fermentasi (DKSF) terhadap deposisi lemak, dan komposisi gizi daging broiler. Dua ratus ekor ayam betina berumur 15 hari didistribusikan ke dalam 5 kelompok perlakuan dengan 4 ulangan sebagai berikut: Kontrol, pakan dengan pakan imbuhan komersial (T0); Pakan dengan 1,25\% DKSF (T1); Pakan dengan DKSF plus 1 g kunyit (T2); Pakan dengan DKSF plus 2 g bawang putih (T3); Pakan dengan DKSF ditambah $1 \mathrm{~g}$ kunyit plus $2 \mathrm{~g}$ bawang putih (T4). Deposisi lemak abdomen sangat nyata meningkat oleh perlakuan $(\mathrm{P}<0,01)$. Lebih lanjut, suplementasi kunyit dan bawang putih ke dalam pakan yang mengandung DKSF tidak mempengaruhi kadar lemak, protein, kelembaban dan abu, tetapi meningkatkan arginin, metionin, dan histidin $(\mathrm{P}<0,01)$. Penambahan kunyit dan/atau bawang putih ke dalam pakan yang mengandung DKSF secara nyata mempengaruhi asam laurat, asam miristat, asam linolenat, asam cis-11-eikosenoat, asam cis-4,7,10,13,16,19docosaheksaenoat $(\mathrm{P}<0,05), \mathrm{n}-3$ asam lemak dan rasio asam lemak n-6/n-3 $(\mathrm{P}<0,01)$. Jadi, suplementasi kunyit plus bawang putih meningkatkan profil asam amino dan mengubah profil asam lemak. Interaksi yang mungkin terjadi harus diperhatikan ketika membuat pakan imbuhan dari campuran tanaman obat.

Kata kunci: kunyit, bawang putih, daun katuk plus salam, deposisi lemak, komposisi gizi daging
\end{abstract}

\begin{abstract}
This study aimed to examine the effect of turmeric and garlic inclusion to fermented Sauropus androgynus-bay leaves (FSBL) containing diet on fat deposition, and chemical composition of broiler meats. Two hundred 15-day-old female broilers were distributed into 5 treatment groups with 4 replications as follows. Control feeds with commercial feed additive (T0); Feeds with $1.25 \%$ FSBL (T1); Feed with FSBL plus $1 \mathrm{~g}$ turmeric (T2); Feed with FSBL plus $2 \mathrm{~g}$ garlic (T3); Feed with FSBL plus $1 \mathrm{~g}$ of turmeric and $2 \mathrm{~g}$ garlic (T4). It was shown that the fat deposition in the abdomen was significantly affected $(\mathrm{P}<0.01)$. Furthermore, the inclusion of turmeric and garlic to FSBL containing diet did not affect fat, protein, moisture and ash contents, but increased arginine, methionine and histidine $(\mathrm{P}<0.01)$. The addition of turmeric and/or garlic to the FSBL containing diet significantly influenced lauric acid, myristic acid, linolenic acid, cis-11-eicosenoic acid, cis-4,7,10,13,16,19docosahexaenoic acid $(\mathrm{P}<0.05), \mathrm{n}-3$ fatty acid and n-6/n-3 fatty acid ratio $(\mathrm{P}<0.01)$. In conclusion, turmeric plus garlic supplementation improved amino acid profiles and changed fatty acid profiles. The
\end{abstract}


possible interaction should be considered when we formulated feed additive from medicinal plant mixtures

Keywords: turmeric, garlic, Sauropus androgynus-bay leaves, fat deposition, meat composition

\section{INTRODUCTION}

Antibiotics that function as growth promoters and optimize product quality have been banned for use by livestock by the Government of Indonesia since 2018. Antibiotics can increase bacterial resistance to drugs, which will complicate the treatment of diseases both in animals and in humans. Besides, the use of antibiotics triggers several diseases in consumers such as allergies. Therefore it is necessary to look for alternative ingredients as a substitute for antibiotics. One alternative to substitute antibiotics is medicinal plants (Nugraha and Keller, 2011; Sugiharto, 2016).

Medicinal plants as the main ingredients in herbal medicine have activities as anti-viral, antimalarial, anti-bacterial and anti-fungal agents (Nugraha and Keller, 2011), anti-inflammatory, anticancer (Faried et al., 2007), antioxidants and antilipids (Aldegbola et al., 2017; Casamassima et al., 2017; Santoso et al., 2018, 2019). Some medicinal plants that are antilipidemic (Casamassima et al., 2017), antioxidant and antimicrobial (Aldegbola et al., 2017 can be mixed into herbal medicine to replace antibiotics. The reduction of fat in poultry is very important because consumers want poultry products that are low in fat and high in protein. The tendency of consumers to consume low-fat poultry products is supported by research results that show a positive correlation between consuming high fat with metabolic disturbances (Ramalho et al., 2017).

Our previous study showed that the inclusion of fermented Sauropus androgynus-bay leaves (FSBL) inclusion at 5\% level reduced fat and cholesterol contents but increased protein and mineral contents (Santoso et al., 2019). This combination of these herbs is still more expensive than commercial feed additive. To reduce feed costs, the use of those herbs needs to be reduced. It was assummed that the decrease in the administration of FSBL will have an impact on the ineffectiveness of the mixture of medicinal plants on decreasing fat deposition and increasing protein deposition in broilers (Santoso et al., 2019). For that, we need to add other medicinal plant ingredients that can be given in small amounts but are thought to be able to reduce the fat deposition. Potential medicinal plants are turmeric and garlic.

Turmeric contains mixed compounds especially sesquiterpenes and curcuminoids (especially curcumin) as the dominant active compounds (Lateef et al., 2016), polyphenols, flavonoids and ascorbic acid (Hossen et al., 2017). Saraswati et al. (2013) reported that turmeric powder inclusion reduced fat and cholesterol contents but increased protein content of quail egg. Daneshyar et al. (2011) reported that the inclusion of turmeric reduced thigh triglyceride, and saturated fatty acid content in the broiler. Garlic powder contains saponins, tannins, alkaloids, and flavonoids (Indrasanti et al., 2017). Kim and Kim (2011) reported that the inclusion of garlic reduced epididymal fat tissue in mice fed high-fat diet. Giving turmeric powder as much as $1 \mathrm{~g} / \mathrm{kg}$ reduces fat in broilers (Samarasinghe et al., 2003), while giving garlic as much as $2 \mathrm{~g} / \mathrm{kg}$ reduces fat in broilers (Jimoh et al., 2012; Samanthi et al., 2015).

The compounds contained in garlic and turmeric as described above have the ability to function as antimicrobial, antioxidant and antilipid. Furthermore, Daneshyar et al. (2011) found that turmeric supplementation increased thigh meat protein. Thus, it is suspected that the addition of garlic and turmeric to the FSBL diet will be able to reduce fat deposition and change meat composition in poultry. In addition, Lee et al. (2012a) reported that garlic supplementation increased glutamic acid, alanine, valine, phenylalanine, eicosapentaenoic acid and docosahexaenoic acid in muscle of fish. Daneshyar et al. (2011) reported that turmeric supplementation reduced saturated fatty acids of broiler meats. The information of garlic and/or turmeric effect on meat amino acids and fatty acids in broiler chick is very limited, and no study was done pertaining to those herbs effect when they are supplemented to FSBL containing diet. This investigation was done to analyze the effect of turmeric and/garlic to FSBL containing diets on fat deposition, nutritional composition, amino acids and fatty acids of broiler meat. It is hypothesized that turmeric and/or garlic inclusion to FSBL containing diets reduced fat deposition, increase protein content, and change fatty acids 
and amino acids composition of broiler meat.

\section{MATERIALS AND METHODS}

\section{Fermentation of Sauropus androgynus and Bay Leaves}

Sauropus androgynus and bay leaves were fermented to decrease antinutrients, crude fiber, and to increases nutritive value (Cui et al., 2012) and nutrient digestibility (Salem et al., 2015). Fermentation was carried out using the method of Santoso et al. (2015) as follows. The leaves that have been cleaned were steamed for 30 minutes. After a cold, the leaves were given $0.5 \%$ cassava yeast and then anaerobically fermented for 24 hours for Sauropus androgynus leaves and 48 hours for bay leaves. Fermented products were then dried, ground and stored in a plastic bag before use.

\section{Animals and Diets}

The experiment was done at Livestock Experiment Unit, Faculty of Agriculture, Bengkulu University. The house, brooder guards, feeders and waterers were cleaned before arriving the chicken. Seven hundred one day broiler chickens were placed into the brooder and reared with a good hygienic condition. Brooder temperature was maintained at $32-33^{\circ} \mathrm{C}$ in the first week and was gradually reduced in the second week, and in the third week, the temperature of the brooder was under the temperature of the enclosure environment. Newly arrived broilers were given coconut sugar containing water to eliminate stress due to travel. At 21 days, broilers were vaccinated with ND (Lasota). The vaccine was given through drinking water. At the age of 1-14 days, broilers were given a commercial diet. Broilers spent 14 days of the brooding period.

At the age of 15 days, female broilers were selected, and distributed into experimental plots and given experimental diet up to the age of 35 days. The diets of $\mathrm{T} 0, \mathrm{~T} 1, \mathrm{~T} 2, \mathrm{~T} 3$, and $\mathrm{T} 4$ contained crude protein levels of 20.0, 19.7, 19.7,

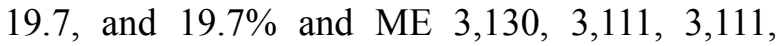
3,111 , and $3,111 \mathrm{kcal} / \mathrm{kg}$, respectively (Table 1 ). Turmeric supplementation at $1 \mathrm{~g} / \mathrm{kg}$ (Samarasinghe et al., 2003) was able to increase body weight and reduce fat deposition in broilers so that this level was used in this study.

This study used a completely randomized

Table 1. The Composition of Experimental Diets

\begin{tabular}{lccccc}
\hline \multicolumn{1}{c}{ Feedstuffs $(\mathrm{g} / \mathrm{kg})$} & $\mathrm{T} 0$ & $\mathrm{~T} 1$ & $\mathrm{~T} 2$ & $\mathrm{~T} 3$ & $\mathrm{~T} 4$ \\
\hline Yellow corn & 582.5 & 582.5 & 581.5 & 580.5 & 579.5 \\
Rice bran & 50 & 40 & 40 & 40 & 40 \\
Broiler concentrate & 342 & 332 & 332 & 332 & 332 \\
Palm oil & 15 & 15 & 15 & 15 & 15 \\
Mineral mixture & 17 & 17 & 17 & 17 & 17 \\
Salt & 1 & 1 & 1 & 1 & 1 \\
Top mix & 5 & 0 & 0 & 0 & 0 \\
FSAL & 0 & 3.125 & 3.125 & 3.125 & 3.125 \\
FBL & 0 & 9.375 & 9.375 & 9.375 & 9.375 \\
Turmeric & 0 & 0 & 1 & 0 & 1 \\
Garlic & 0 & 0 & 0 & 2 & 2 \\
Total & 1,000 & 1,000 & 1,000 & 1,000 & 1,000 \\
ME, kcal/kg & 3,130 & 3,111 & 3,111 & 3,110 & 3,110 \\
Protein, \% & 20.0 & 19.7 & 19.7 & 19.7 & 19.7 \\
\hline
\end{tabular}

$\mathrm{FSAL}=$ Fermented Sauropus androgynus leaves; $\mathrm{FBL}=$ Fermented bay leaves 
design. Two hundred 15-day-old female broilers were distributed into 5 treatment groups with 4 replications $(10$ female broilers of each replication) as follows. Control feeds with commercial feed additive (T0); Feeds with $1.25 \%$ FSBL (T1); Feed with FSBL plus $1 \mathrm{~g}$ turmeric (T2); Feed with FSBL plus 2 g garlic (T3); Feed with FSBL plus $1 \mathrm{~g}$ of turmeric and $2 \mathrm{~g}$ garlic (T4). Broilers were maintained according to standard broiler maintenance procedures and were given diet and drinking water ad libitum. Broilers were kept in a $1 \times 1 \mathrm{~m}$ bamboo enclosure on a rice husk base of $5 \mathrm{~cm}$ thickness for 21 days.

\section{Sampling}

At 35 days of age, 4 female broilers for each treatment group were slaughtered. The accumulation of fat in the abdomen, gizzard, leg meats, heart, and neck were taken and weighed. To measure fatty liver scores, the colors of the broiler livers were compared with the standard colors from 1 to 5 (from dark brown (value 1) to yellowish-white (value 5). The higher the value, the higher the fat content. The broiler thigh meats were taken, milled and frozen before analysis.

\section{Laboratory Analysis}

Fat content was analyzed by Soxhlet extraction; moisture content was analyzed by drying the samples at $105^{\circ} \mathrm{C}$, and protein content was analyzed using macro Kjeldahl (AOAC, 1990). The amino acid composition was measured by the method described by Ginting et al. (2017). Sixty milligrams of broiler thigh meat in erlenmeyer was added $4 \mathrm{ml}$ of $6 \mathrm{~N} \mathrm{HCl}$ and refluxed for 24 hours at $110^{\circ} \mathrm{C}$. The results of hydrolysis were neutralized with $\mathrm{NaOH} 6 \mathrm{~N}$ and filtered with $0.2 \mu \mathrm{m}$ wattman paper. $50 \mu \mathrm{l}$ was taken and $300 \mu \mathrm{L}$ OPA (O-phthalaldehyde) solution and 1-2 drops of 2-mercaptoetanol was added and stirred for 5 minutes. Furthermore, a sample of $20 \mu \mathrm{L}$ was inserted into the HPLC injector alternately and ready for analysis. For analysis of fatty acid composition, twenty gram broiler thigh meat was dried at $90^{\circ} \mathrm{C}$ for 24 hours. The sample was extracted in the soxhlet for 16 hours. The extraction was concentrated at $55^{\circ} \mathrm{C}$ for 2 hours. A total of $0.0298 \mathrm{~g}$ of sample was added to $1 \mathrm{~mL}$ of $\mathrm{NaOH} 0.5 \mathrm{~N}$ within methanol and heated over a water bath at $80^{\circ} \mathrm{C}$ for 20 minutes. After cooling, $2 \mathrm{~mL} \mathrm{BF} 3$ was added and heated at $80^{\circ} \mathrm{C}$ for 20 minutes, then cooled and added $2 \mathrm{~mL}$ of saturated $\mathrm{NaCl}$ and $1 \mathrm{~mL}$ of hexane. The hexane layer was separated by a dropping pipette and put in a tube containing 0.1 grams of $\mathrm{Na}_{2} \mathrm{SO}_{4}$ anhydrous, and left for 15 minutes. Sample solutions were separated and ready to be injected. The fatty acid composition was then measured by gas chromatography (Trembeka et al., 2013).

The results of the study were analyzed by ANOVA and if significantly different were tested further with Duncan's Multiple Range Test. The fatty liver score was qualitatively analyzed.

\section{RESULTS AND DISCUSSIONS}

\section{Fat Deposition}

Effect of turmeric and garlic inclusion to fermented Sauropus androgynus-bay leaves on fat deposition in female broiler chickens is presented in Table 2 . It was shown that the fat deposition in the gizzard, proventriculus, sartorial, neck and heart was not affected $(\mathrm{P}>0.05)$, whereas abdominal fat was significantly increased $(\mathrm{P}<0.05)$. T2, and T3 had higher abdominal fat than $\mathrm{T} 0$. The reduction of a fatty liver score in $\mathrm{T} 1$, $\mathrm{T} 2$, T3, and $\mathrm{T} 4$ as compared with $\mathrm{T} 0$ was $37.5 \%$, $3 \%, 37.5 \%$, and $18.5 \%$, respectively.

It is unknown why the inclusion of turmeric (T2) or garlic (T3) increased abdominal fat depot. When two herbs are mixtured, the compounds of those herbs may interact to each other, either synergistic or antagonism interaction. Since the inclusion $1 \mathrm{~g}$ turmeric $/ \mathrm{kg}$ (Samarasinghe et al., 2003), and the inclusion of $2 \mathrm{~g}$ garlic/kg (Jimoh et al., 2012; Samanthi et al., 2015) lowered abdominal fat depots, it appears that there is antagonism interaction between turmeric or garlic with Sauropus androgynus-leaves when they are mixtured. Han et al. (2012) reported that unfavorable combinations of flavonoids and carotenoids resulted in antioxidant antagonism despite large potential differences. Thus, the combination of carotenoids and flavonoids in Sauropus androgynus plus in turmeric or garlic may result in antagonism interaction, and therefore it may reduce antilipid properties of those medicinal plants.

Lower fatty liver scores in T1, T2, T3, and T4 indicated lower fat content in the liver. This result showed that the addition of turmeric or garlic to the FSBL containing diet was not able to lower the fatty liver score further. Lower fat content in the liver would partly reduce the risk of fatty liver syndrome occurrence in broiler chickens. Decreased levels of fat in the liver are 
Table 2. Effect of Turmeric and Garlic Inclusion to Fermented Sauropus androgynus-Bay Leaves on Fat Deposition in Female Broiler Chickens

\begin{tabular}{lcccccc}
\hline Fat Deposition, $\%$ & $\mathrm{~T} 0$ & $\mathrm{~T} 1$ & $\mathrm{~T} 2$ & $\mathrm{~T} 3$ & $\mathrm{~T} 4$ & $\mathrm{P}$ \\
\hline Neck & $0.08 \pm 0.01$ & $0.11 \pm 0.03$ & $0.09 \pm 0.02$ & $0.07 \pm 0.01$ & $0.09 \pm 0.01$ & 0.154 \\
Heart & $0.11 \pm 0.03$ & $0.11 \pm 0.02$ & $0.09 \pm 0.02$ & $0.09 \pm 0.02$ & $0.11 \pm 0.01$ & 0.541 \\
Proventriculus & $0.09 \pm 0.01$ & $0.10 \pm 0.01$ & $0.09 \pm 0.02$ & $0.10 \pm 0.02$ & $0.11 \pm 0.03$ & 0.758 \\
Gizzard & $0.37 \pm 0.10$ & $0.30 \pm 0.05$ & $0.34 \pm 0.06$ & $0.36 \pm 0.04$ & $0.37 \pm 0.08$ & 0.562 \\
Sartorial & $0.21 \pm 0.05$ & $0.22 \pm 0.04$ & $0.24 \pm 0.06$ & $0.26 \pm 0.06$ & $0.26 \pm 0.07$ & 0.645 \\
Abdomen & $0.71 \pm 0.06^{\mathrm{a}}$ & $0.81 \pm 0.04^{\mathrm{ab}}$ & $0.86 \pm 0.04^{\mathrm{b}}$ & $0.85 \pm 0.09^{\mathrm{b}}$ & $0.76 \pm 0.09^{\mathrm{ab}}$ & 0.035 \\
Total fat deposition & $1.59 \pm 0.15$ & $1.64 \pm 0.13$ & $1.72 \pm 0.13$ & $1.75 \pm 0.17$ & $1.68 \pm 0.13$ & 0.542 \\
Fatty liver score & $2.00 \pm 0.41$ & $1.25 \pm 0.29$ & $1.94 \pm 0.31$ & $1.25 \pm 0.50$ & $1.63 \pm 0.48$ & \\
\hline
\end{tabular}

$\mathrm{T} 0=$ Control without herbs; $\mathrm{T} 1=$ Feeds with $1.25 \%$ fermented Sauropus androgynus -bay leaves (FSBL)]; T2 $=$ Feed with FSBL plus $1 \mathrm{~g}$ turmeric powder; $\mathrm{T} 3=$ Feed with FSBL plus $2 \mathrm{~g}$ garlic); $\mathrm{T} 4=$ Feed with FSBL plus $1 \mathrm{~g}$ turmeric and $2 \mathrm{~g}$ garlic.

caused partly by a decrease in fatty acid synthesis and/or an increase in fatty acid degradation in the liver.

\section{Meat Composition}

The effect of turmeric and garlic inclusion to fermented Sauropus androgynus-bay leaves on meat composition of female broiler chickens is shown in Table 3. It was shown that the inclusion of turmeric and garlic to the FSBL containing diet did not affect fat, protein, moisture and ash contents $(\mathrm{P}>0.05)$. Although the effect was not significant, $\mathrm{T} 1$ tended to have lower fat content than $\mathrm{T} 0$ of $24.4 \%$. This shows that the decrease in the level of Sauropus androgynus plus bay leaves administration from 2.5\% (Santoso et al., 2019) to $1.25 \%$ is still able to reduce the level of meat fat. Santoso et al. (2018) found that the addition of Sauropus androgynus leaf or bay leaf at 5\% level reduced meat fat content by $26.7 \%$ or $10.0 \%$, respectively. When these herbs were fermented, combined, and fed at a level of $2.5 \%$ or $5 \%$ they reduced meat fat content ranging from $22.5 \%$ to $45.2 \%$ (Santoso et al., 2019). When the fermented Sauropus androgynus plus bay leaves feeding was reduced at $1.25 \%$ just reduced fat content at $24,4 \%$. Thus, the feeding level of that mixture may influence fat content. A fermented product has been known to reduce the meat fat content in broiler chickens (Santoso et al., 2010). A reduction in the carcass fat content by fermented product was partly caused by a reduction of fatty acid synthesis (Nie et al., 2015). Flavonoids (Zarrouki et al., 2010), tannins (Selvi and Bhaskar, 2012) and phenols (Qiong et al., 2014) have been reported to have anti lipid properties. $\mathrm{Li}$ and Tian (2004) also reported that flavonoids inhibited fatty acid synthase activity. Supplementation of $1 \mathrm{~g}$ turmeric/kg diet and/or 2 $\mathrm{g}$ garlic/kg diet to FSBL containing diet tended to increase meat fat content. Antioxidant antagonism might play an important role in the tendency of meat fat accretion.

The present study showed that $1.25 \%$ FSBL did not increase the protein content of broiler meat. This result was similar to Santoso et al. (2019) who reported that giving 2.5-5\% FSBL did not increase protein content. Thus, FSBL feeding could be reduced to $1.25 \%$ level without reducing protein content. The inclusion of $1 \mathrm{~g}$ turmeric $/ \mathrm{kg}$ and/or $2 \mathrm{~g}$ garlic/kg to FSBL containing diet did also not increase protein content. Dzinic et al. (2013) reported that giving 2\% garlic did not increase protein content. Kanani et al. (2017) reported that giving $0.5 \%$ turmeric powder did not increase protein content.

\section{Amino Acid Profile of Broiler Meat}

Table 4 shows the effect of turmeric and garlic to fermented Sauropus androgynus-bay leaves on meat amino acid composition of female broilers. The results of this research showed that 
Table 3. The Effect of Turmeric and Garlic Inclusion to Fermented Sauropus androgynus-Bay Leaves on Meat Composition of Female Broiler Chickens

\begin{tabular}{lrrrrrr}
\hline Variables (\%) & \multicolumn{1}{c}{$\mathrm{T} 0$} & \multicolumn{1}{c}{$\mathrm{T} 1$} & \multicolumn{1}{c}{$\mathrm{T} 2$} & \multicolumn{1}{c}{$\mathrm{T} 3$} & \multicolumn{1}{c}{$\mathrm{T} 4$} & $\mathrm{P}$ \\
\hline Fat & $5.00 \pm 1.52$ & $3.78 \pm 0.94$ & $5.34 \pm 0.45$ & $4.02 \pm 0.44$ & $4.22 \pm 0.78$ & 0.108 \\
Moisture & $75.19 \pm 2.33$ & $75.80 \pm 1.34$ & $74.16 \pm 0.38$ & $75.56 \pm 0.83$ & $75.34 \pm 0.93$ & 0.495 \\
Protein & $19.00 \pm 0.67$ & $19.28 \pm 0.45$ & $19.16 \pm 0.26$ & $19.27 \pm 0.37$ & $19.34 \pm 0.05$ & 0.880 \\
Ash & $1.34 \pm 0.12$ & $1.15 \pm 0.15$ & $1.34 \pm 0.10$ & $1.16 \pm 0.19$ & $1.11 \pm 0.12$ & 0.074 \\
\hline
\end{tabular}

$\mathrm{T} 0=$ Control without herbs; $\mathrm{T} 1=$ Feeds with $1.25 \%$ fermented Sauropus androgynus-bay leaves (FSBL)]; T2 $=$ Feed with FSBL plus $1 \mathrm{~g}$ turmeric powder; $\mathrm{T} 3=$ Feed with FSBL plus $2 \mathrm{~g}$ garlic); T4 = Feed with FSBL plus $1 \mathrm{~g}$ turmeric and $2 \mathrm{~g}$ garlic.

Table 4. The Effect of Turmeric and Garlic to Fermented Sauropus androgynus-Bay Leaves on Meat Amino Acid Composition of Female Broilers

\begin{tabular}{lllllll}
\hline Amino acid $(\%)$ & \multicolumn{1}{c}{$\mathrm{T} 0$} & \multicolumn{1}{c}{$\mathrm{T} 1$} & \multicolumn{1}{c}{$\mathrm{T} 2$} & \multicolumn{1}{c}{$\mathrm{T} 3$} & $\mathrm{~T} 4$ & $\mathrm{P}$ \\
\hline Aspartic acid & $1.64 \pm 0.04$ & $1.71 \pm 0.03$ & $1.83 \pm 0.17$ & $1.82 \pm 0.22$ & $1.88 \pm 0.04$ & 0.094 \\
Glutamic acid & $3.21 \pm 0.07$ & $3.22 \pm 0.13$ & $3.34 \pm 0.19$ & $3.30 \pm 0.33$ & $3.553 \pm 0.02$ & 0.106 \\
Serine & $0.67 \pm 0.01$ & $0.67 \pm 0.02$ & $0.69 \pm 0.03$ & $0.66 \pm 0.06$ & $0.72 \pm 0.01$ & 0.154 \\
Histidine & $0.54 \pm 0.02^{\mathrm{ab}}$ & $0.59 \pm 0.03^{\mathrm{c}}$ & $0.53 \pm 0.01^{\mathrm{a}}$ & $0.56 \pm 0.03^{\mathrm{abc}}$ & $0.57 \pm 0.01^{\mathrm{bc}}$ & 0.013 \\
Glycine & $0.86 \pm 0.09$ & $0.93 \pm 0.053$ & $1.03 \pm 0.11$ & $1.07 \pm 0.22$ & $1.06 \pm 0.12$ & 0.171 \\
Threonine & $0.73 \pm 0.03$ & $0.75 \pm 0.02$ & $0.76 \pm 0.03$ & $0.73 \pm 0.07$ & $0.81 \pm 0.02$ & 0.109 \\
Arginine & $1.24 \pm 0.08^{\mathrm{a}}$ & $1.24 \pm 0.16^{\mathrm{a}}$ & $1.15 \pm 0.03^{\mathrm{a}}$ & $1.18 \pm 0.15^{\mathrm{a}}$ & $1.57 \pm 0.01^{\mathrm{b}}$ & 0.000 \\
Alanine & $1.19 \pm 0.13$ & $1.09 \pm 0.07$ & $1.16 \pm 0.07$ & $1.14 \pm 0.16$ & $1.23 \pm 0.04$ & 0.429 \\
Tyrosine & $0.54 \pm 0.04$ & $0.57 \pm 0.01$ & $0.56 \pm 0.01$ & $0.57 \pm 0.06$ & $0.62 \pm 0.01$ & 0.075 \\
Methionine & $0.42 \pm 0.04^{\mathrm{a}}$ & $0.44 \pm 0.01^{\mathrm{a}}$ & $0.45 \pm 0.02^{\mathrm{a}}$ & $0.44 \pm 0.04^{\mathrm{a}}$ & $0.50 \pm 0.01^{\mathrm{b}}$ & 0.023 \\
Valine & $0.775 \pm 0.06$ & $0.82 \pm 0.02$ & $0.84 \pm 0.03$ & $0.81 \pm 0.07$ & $0.88 \pm 0.00$ & 0.061 \\
Phenylalanine & $1.04 \pm 0.08$ & $1.08 \pm 0.07$ & $0.98 \pm 0.02$ & $1.23 \pm 0.33$ & $1.08 \pm 0.01$ & 0.249 \\
I-leucine & $0.81 \pm 0.06$ & $0.84 \pm 0.04$ & $0.84 \pm 0.02$ & $0.83 \pm 0.07$ & $0.89 \pm 0.02$ & 0.212 \\
Leucine & $1.44 \pm 0.09$ & $1.46 \pm 0.05$ & $1.47 \pm 0.04$ & $1.47 \pm 0.14$ & $1.59 \pm 0.01$ & 0.117 \\
Lysine & $1.58 \pm 0.12$ & $1.47 \pm 0.26$ & $1.31 \pm 0.50$ & $1.63 \pm 0.14$ & $1.74 \pm 0.04$ & 0.182 \\
Total & $16.72 \pm 0.54$ & $16.91 \pm 0.55$ & $16.96 \pm 0.91$ & $17.46 \pm 1.90$ & $18.70 \pm 0.15$ & 0.080 \\
\hline
\end{tabular}

$\mathrm{T} 0=$ Control without herbs; $\mathrm{T} 1=$ Feeds with $1.25 \%$ fermented Sauropus androgynus-bay leaves (FSBL)]; T2 $=$ Feed with FSBL plus $1 \mathrm{~g}$ turmeric powder; T3 = Feed with FSBL plus $2 \mathrm{~g}$ garlic); T4 = Feed with FSBL plus $1 \mathrm{~g}$ turmeric and $2 \mathrm{~g}$ garlic.

turmeric and/ or garlic addition to FSBL containing diet significantly increased arginine, and methionine $(\mathrm{P}<0.05)$, and tended to increased aspartic acid, tyrosine, valine, and total amino 
acid. FSBL containing diet (T1) had higher histidine than $\mathrm{T} 0$, but the inclusion of turmeric to FSBL containing diet (T2) reduced it $(\mathrm{P}<0.05)$.

The inclusion of turmeric plus garlic to FSBL increased arginine, and methionine and tended to increased aspartic acid, tyrosine, valine, and total amino acid. Also, the present study showed that garlic was more effective than turmeric in increasing those amino acids. Lee et al. $\left(2012^{\mathrm{a}}\right)$ reporte that garlic supplementation increase glutamic acid, alanine, valine, leucine, phenylalanine, and total amino acid in fish (Lee et al., 2012a). They showed that garlic inclusion improved body weight and nitrogen retention (Lee et al., 2012b). Garlic is rich in organosulfur compounds such as allicin, S-allyl cysteine, diallyl disulfide, S-methyl cysteine sulfoxide and S-allyl cysteine. The sulfur compounds may contribute to insulin synthesis. An increase in insulin concentration may induce acceleration for blood free amino acid uptake into muscle. The presence of sulfur from garlic might also increase the synthesis of methionine by bacteria in the digestive tract and can then be absorbed by the body. In addition, fermentation may increase the availability of methionine. Turmeric plus garlic inclusion increased the arginine content of broiler meat. Turmeric or garlic inclusion individually did not increase arginine content, and therefore it could be predicted that there is synergistic interaction between them in increasing arginine content.

Saccharomyces cerevisiae (cassava yeast) could synthesize histidine from 5-phospho- $\alpha$-Dribose-1-diphospate. It assumes that during fermentation of Sauropus androgynus and bay leaves, histidine is synthesized so that the histidine content of those leaves increases. This may contribute to an increase in histidine of broiler meat fed $1.25 \%$ FSBL containing diet. In additon, fermentation may increase the availability of histidine. It is unknown why turmeric inclusion to FSBL containing diet reduced histidine.

\section{Fatty Acid Profile of Broiler Meat}

The effect of turmeric and garlic inclusion to fermented Sauropus androgynous-bay leaves on meat fatty acid of female broilers is presented in Table 5 . These results showed that the addition of turmeric and/or garlic to the FSBL containing diet significantly influenced lauric acid, myristic acid, linolenic acid, cis-11-eicosenoic acid, cis4,7,10,13,16,19-docosahexaenoic acid $(\mathrm{P}<0.05)$, n-3 fatty acid and n-6/n-3 fatty acid ratio $(\mathrm{P}<0.01)$. Lauric acid of T0 was higher than the other groups. Myrictic acid of T0 was higher than $\mathrm{T} 1, \mathrm{~T} 2, \mathrm{~T} 3$, and $\mathrm{T} 4$, whereas $\mathrm{T} 1$ and $\mathrm{T} 2$ had higher myristic acid than $\mathrm{T} 3$ but similar to $\mathrm{T} 4$. Linolenic acid of T0, T1, and T2 was higher than T3. cis-11-eicosenoic acid of T0, T1, T2, and T3 was higher than T4. Cis-4,7,10,13,16,19docosahexaenoic acid of T0 was higher than T3 and $\mathrm{T} 4$, whereas $\mathrm{T} 1$ and $\mathrm{T} 2$ were not different from T0, T3, and T4. Fatty acid n-3 of T0, T1, and $\mathrm{T} 2$ was higher than $\mathrm{T} 3$, and $\mathrm{T} 4$. $\mathrm{N}-6 / \mathrm{n}-3$ ratio of $\mathrm{T} 0$ was lower than $\mathrm{T} 3$ and $\mathrm{T} 4$, whereas $\mathrm{T} 1$, and $\mathrm{T} 2$ were lower than T3 but similar to T4.

Daneshyar et al. (2011) reported that $0.25 \%$ $(2.5 \mathrm{~g} / \mathrm{kg})$ turmeric powder inclusion did change the fatty acid composition of broiler chickens. The present study showed that $1 \mathrm{~g}$ turmeric $/ \mathrm{kg}$ inclusion to FSBL reduced only myristic acid. However, garlic differs from turmeric in which it changes more fatty acids. The inclusion of garlic to FSBL containing diet reduced myristic acid, linolenic acid, n-3 fatty acid but increased n-6/n-3 fatty acid ratio.

A reduction of myristic acid by FSBL as compared with the control group (T0) agrees with the observation of Santoso et al. (2019) who reported the inclusion of FSBL reduced myristic acid of broiler meat. Supplementation of $2 \mathrm{~g}$ garlic into the FSBL containing diet could reduce myristic acid higher so that the level is lower than the FSBL group (T1). It is suspected that there is a synergy interaction between FSBL and garlic in reducing myristic acid since Kim et al. (2009) showed that giving $2 \%$ garlic did not reduce myristic acid. This presumption does not apply to turmeric supplementation to the FSBL containing diet, because turmeric was not able to further reduce myristic acid. Temme et al. (1997) reported that myristic acid increased low density lipoprotein (LDL) cholesterol of healthy human. A similar result was reported by Zock et al. (1994) who found that myristic acid increased LDL cholesterol, apoB, and low HDL to LDL ratio. Thus, reducing broiler meat myristic acid may be beneficial for consumers.

Linolenic acid reduced in broilers fed FSBL plus garlic when compared to those fed $1.25 \%$ FSBL. Kim et al. (2009) reported that giving 2\% garlic did not change linolenic acid. Therefore, a negative interaction between FSBL and garlic is suspected, which causes a decrease in linolenic acid. Supplementation of $1 \mathrm{~g}$ turmeric into FSBL plus garlic could increase levels of linolenic acid 


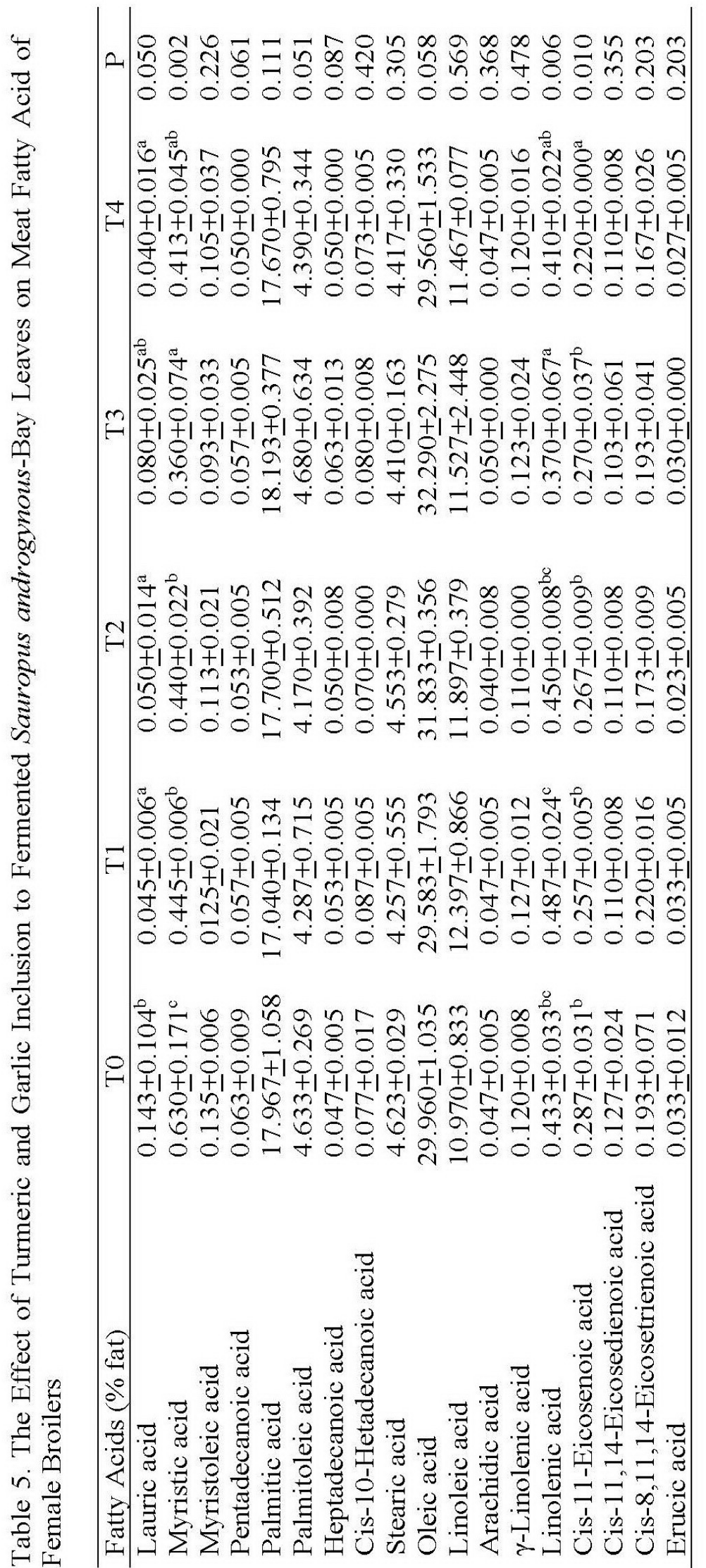




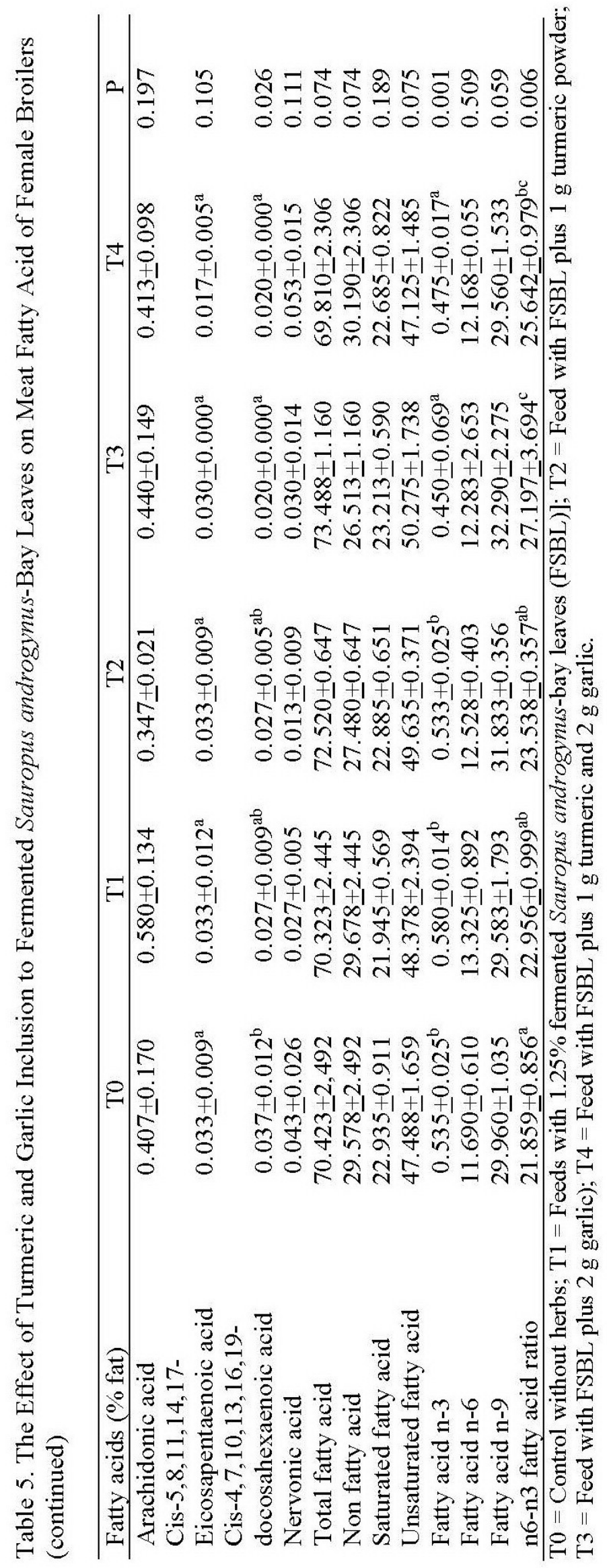


so that it is relatively the same as the control but still below T1. Stark et al. (2008) stated that linolenic acid had an important role in cardioprotective effect, modulation of the inflammatory response, and central nervous system function. Thus, the inclusion of garlic to the FSBL containing diet has a negative effect, namely lowering linolenic acid. It is recommended that palm oil in this study can be replaced with a linolenic acid source oil.

Cis-11-eicosenoic acid is not produced by humans and comes from the diet. It has been found in the red blood cell membrane with increased concentrations in children with regressive autism (Bu et al., 2006). Delgado et al. (2017) cis-11-eicosenoic acid has direct correlations with markers of inflammation and endothelial activations as well as heart failure in humans. Thus, a decrease in this fatty acid by the inclusion of garlic plus turmeric to FSBL containing diet may be beneficial for consumers. DHA was decreased by garlic plus FSBL (T3) compared to the control but tends to decrease when compared to FSBL (T1), while T1 is relatively the same as T0. From these data, it can be assumed that there is a negative interaction between FSBL and garlic so that DHA levels at T3 are lower than T0. DHA levels remain lower than the control group although turmeric was added to FSBL containing diet plus garlic..

Based on the description above, when we formulate feed additive from medicinal plants, it is necessary to consider interactions between the compounds contained in medicinal plants, so that the feed additive prepared will have a synergistic interaction.

\section{CONCLUSION}

The inclusion of turmeric plus garlic to FSBL containing diet increased arginine, and methionine, and tended to increased aspartic acid, tyrosine, valine and total amino acid of broiler meats. Thus, turmeric plus garlic supplementation improved amino acid profiles of broiler meats. Turmeric plus garlic to FSBL containing diet reduced myristic acid, linolenic acid, cis-11eicosenoic acid, n-3 fatty acids but increased n6n3 fatty acid ratio. The inclusion of turmeric and/or garlic did not change moisture, fat, protein and ash contents of broiler meats. The possible interaction should be considered when we formulated feed additive from medicinal plant mixtures

\section{ACKNOWLEDGMENTS}

The authors thank the Director General of Higher Education, the Ministry of Research, Technology and Higher Education, Indonesia under contract number 769/UN30.15/LT/2019. The authors are also grateful to Kiki Rusdi, Elsa Marta Savitri, and Novriska Winni Simanjutak for assisting in the conduct of this research.

\section{REFERENCES}

Adegbola, P., I. Aderibigbe, W, Hammed and T. Omatayo. 2017. Antioxidant and antiinflammatory medicinal plants have potential role in the treatment of cardiovascular disease: a review. Am.J. Cardiovasc. Dis. 2017; 7(2): 19-32.

A O A C. 1990. Official Methods of Analysis. Association of Official Analytical Chemist, Inc., Arlingtong, Virginia. Breuer, G., W.A.C. Evers, J.H. de Vree, D.M.M. Kleinegris, D.E. Martens, R.H. Wijffels and P.P. Lamers. 2013. Analysis of fatty acid content and composition in microalgae. J. Vis. Exp. E50628.

Bu, B., P. Ashwood, D. Harvey, I.B. King, J.V. Water and L.W. Jin. 2006. Fatty acid compositions of red blood cell phospholipids in children with autism. Prostaglandins Leukot. Essent. Fatty Acids 74(4):215-221.

Casamassima, D., M. Palazzo, F. Vizzarri, R. Coppola, C. Costagliola and C. Corino. 2017. Dietary effect of dried bay leaves (Laurus nobilis) meal on some biochemical parameters and on plasma oxidative status in New Zealand white growing rabbit. J. Anim. Physiol. Anim. Nutr. 101:e175-e184.

Cui, L., D.J. Li and C.Q Liu. 2012. Effect of fermentation on the nutritive value of maize. Int. J. Food Sci. Technol. 47: 755-760.

Daneshyar, M., M. Alizadeh-Ghandkanlo, F. Sabzi-Bayeghra, F. Farhangpajhoh and M. Aghaei. 2011. Effects of dietary turmeric supplementation on plasma lipoproteins, meat quality and fatty acid composition in broilers. South African J. Anim. Sci. 41 (4):420-428.

Delgado, G.E., B.K. Kramer, S. Lorkowski, W. Marz, C. von Schacky and M.E. Kleber. 2017. Individual omega-9 monounsaturated fatty acids and mortality - The ludwigshafen risk and cardiovascular health study. J. Clin. 
Lipidol. 11(1): 126-135.e5.

Dzinic, N., D. Okanovic, M. Jokanovic, V. Tomovic and D. Palk. 2013. The influence of garlic powder in broiler feed on carcass and breast meat quality. Quality of Life 4: 55-61.

Faried, A., D. Kurnia, L.S. Faried, N. Usman, T. Miyazaki, H. Kato and H. Kuwano. 2007. Anticancer effects of gallic acid isolated from Indonesian herbal medicine, Phaleria macrocarpa (Scheff.) Boerl, on human cancer cell lines. Int. J. Oncol. 30:605-613,

Ginting, A.R., S. Sitorus and W. Astuti. 2017. Penentuan kadar asam amino esensial pada telur penyu dan telur bebek. Jurnal Kimia Mulawarman 14(2): 91-99.

Han, R.M., J.P. Zhang and L.H. Skibsted. 2012. Reaction dynamics of flavonoids and carotenoids as antioxidant. Molecules 17: 2140-2160.

Hossen, Md. S., E.M. Tanvir, M.B. Prince, S. Paul, M. Saha, Md. Y. Ali, S.H. Gan, Md. I. Khalil and N. Karim. 2017. Protictive mechanism of turmeric (Curcuma longa) on carboburan-induced hematological and hepatic toxicities in a rat model. Pharma. Biol. 55(1):1937-1945.

Indrasanti, D., M. Indradji, S. Hastuti, E. Aprilliyanti, Fatikha and K.A. Rosyadi. 2017. The administration of garlic extract on Eimeria stiedai oocysts and the hematological profile of the coccidia infected rabbits. Media Peternakan 40(3): 158-164.

Jimoh A.A., B.R. Olorede, A. Abubakar, J.P. Fabiyi, E.B. Ibitoye, N. Suleiman and S. Garba. 2012. Lipids profile and haematological indices of broiler chickens fed garlic (Allium sativum) - supplemented diets. J. Vet. Adv. 2(10):474-480.

Kanani, P. G., M. Daneshyar, J. Aliakbarlu and F. Hamian. 2017. Effect of dietary turmeric and cinnamon powders on meat quality and lipid peroxidation of broiler chicken under heat stress condition. Vet. Res. Forum 8(2):163-169.

Kim, Y.J., S.K. Jin and H.S. Yang. 2009. Effect of dietary garlic bulb and husk on the physicochemical properties of chicken meat. Poultry Sci. 88:398-405.

Kim, M.J. and H.K. Kim. 2011. Effect of garlic on high fat induced obesity. Acta Biol. Hung. 62(3):244-254.

Lateef, E.A., F. Mahmoud, O. Hammam, E. El-
Ahwany, E. El-Wakil, S. Kandil, H.A. Taleb, M. El-Sayed and H. Hassenein. 2016. Bioactive chemical constituents of Curcuma longa $\mathrm{L}$. rhizomes extract inhibit the growth of human hepatoma cell line (HepG2). Acta Pharma. 66:387-398.

Lee, D.H., S. R. Lim, C.S. Ra, and J.D. Kim. 2012a. Effects of dietary garlic extracts on whole body amino acid and fatty acid composition, muscle free amino acid profiles and blood plasma changes in juvenile sterlet sturgeon, Acipenser ruthenus. Asian-Aust. J. Anim. Sci. 25:1419-1429.

Lee, D.H., C.S. Ra, Y.H. Song, K.I. Sung and J.D. Kim. 2012b. Effect of dietary garlic extracts on growth, feed utilization and whole body composition of juvenile sterlet sturgeon (Acipenser ruthenus). Asian-Aust. J. Anim. Sci. 25:577-583.

Li, B.H. and W.X. Tian. 2004. Inhibitory effects of flavonoids on animal fatty acid synthase. J. Biochem. 135(1):85-91.

Nie, C.X., W.J. Zhang, W.X. Ge, Y.P.Yiu, Y.Q.Wang and J.C. Liu. 2015. Effect of cottonseed meal fermented with yeast on the lipid-related gene expression in broilermchickens. Bra. J. Poultry Sci., Special Issue Nutrition-Poultry Feeding Additives/057-064., October-December 2015.

Nugraha, A.S. and P.A. Keller. 2011. Revealing indigenous Indonesian traditional medicine: anti-infective agents. Nat. Prod. Commun. 6(12):1953-1966.

Qiong, F., Z. Chong, Z. Min, D. Aini and Y. Hanhui. 2014. Determination of total polyphenols in Sauropus androgynus by Folin-Ciocalteu colorimetric method. J. South. Agric. 45(12):2230-2235.

Ramalho, L., M.N. Da Jornada, L.C. Antunes and M.P. Hidalgo. 2017. Metabolic disturbances due to a high-fat diet in a noninsulin-resistant animal model. Nutr. Diabetes 7(3): e245.

Salem, A.Z.M., H. Alsersy, L.M. Camacho, M.M. El-Adawy, M.M.Y. Elghandour, A.E. Kholif, N. Rivero, M.U. Alonso and A. Zaragoza. 2015. Feed intake, nutrient digestibility, nitrogen utilization, and ruminal fermentation activities in sheep fed Atriplex halimus ensiled with three developed enzyme cocktail. Czech J. Anim. Sci. 60: 185-194. 
Samanthi, K.A.M., W.A.D. Nayananjalie, A.M.J.B. Adikari and R. Liyanage. 2015. Dietary garlic (Allium sativum L.) supplementation on performance, meat quality and lipid profile in broilers. Rajarata University J. 3: 17-24.

Samarasinghe, K., C. Wenk, K.S.E.T. Silva and J.M.D.M. Gunasekera. 2003. Turmeric (Curcuma longa) root powder and mannanoligosaccharides as alternatives to antibiotics in broiler chicken diets. AsianAust. J. Anim. Sci. 16(10):1495-1500.

Santoso, U., S. Ishikawa and K. Tanaka. 2010. Effect of fermented chub mackerel extract on lipid metabolism of diabetic rats. J. Indonesian Trop. Anim. Agric. 35:158-164.

Santoso, U., Y. Fenita, Kususiyah, I.G.N.G. Bidura. 2015. Effect of fermented Sauropus androgynus leaves on meat composition, amino acid and fatty acid compositions in broiler chickens. Pak. J. Nutr. 14:799-807.

Santoso, U., Y. Fenita, Kususiyah, O. Widiantoro and S. Kadarsih. 2018. The effect of medicinal herb on fat deposition, meat composition, amino acid and fatty acid composition of broiler meats. J. Indonesian Trop. Anim. Agric. 43(1):54-65.

Santoso, U., Y. Fenita and Kususiyah. 2019. The usefulness of fermented katuk (Sauropus androgynus) plus bay leaves to modify fat accumulation, cholesterol and chemical composition of broiler meat. J. Indonesian Trop. Anim. Agric. 44(1):84-95.

Saraswati, T.R., W. Manalu, D.R. Ekastuti and N. Kusumorini. 2013. The role of turmeric podwer in lipid metabolism and its effect on quality of the first quail's egg. J. Indonesian Trop. Anim. Agric. 38(2):123-130.

Selvi, V.S. and A. Bhaskar. 2012. Phytochemical analysis and GC-MS profiling in the leaves of Sauropus Androgynus (L) Merr. Int. J. Drug Dev. Res. 4(1):162-167.

Stark, A.H., M.A. Crawford and R. Reifen. 2008. Update on alpha-linolenic acid. Nutr. Rev. 66(6):326-332.

Sugiharto, S. 2016. Role of nutraceuticals in gut healthand growth performance of poultry. J. Saudi Soc. Agric. Sci. 15:99-111.

Temme, E.H., R.P. Mensik and G. Homstra. 1997. Effect of medium chain fatty acids (MCFA), myristic acid, and oleic acid on serum lipoproteins in healthy subjects.J. Lipid. Res. 38(9):1746-1754.

Trembecka, L., P. Hascik, J. Cubon, M. Bobko and A. Pavelkova. 2016. Fatty acids profile of breast and thigh muscles of broiler chickens fed diets with propolis and probiotics. J. Central Eur. Agric. 17 (4): 1179-1193.

Zarrouki, B., N. J. Pillon, E. Kalbacher, H. A. Soula, G. Nia N'Jomen, L. Grand, S. Chambert, A. Geloen and C.O. Soulage, 2010. Cirsimarin, a potent antilipogenic flavonoid, decreases fat deposition in mice intra-abdominal adipose tissue. Int. J. Obes. (Lond.). 34:1566-75.

Zock, P.L., J.H. de Vries and M.B. Katan. 1994. Impact of myristic acid versus palmitic acid on serum lipid and lipoprotein levels in helathy women and men. Arthioscler. Thromb. 14(4): 567-575. 